\title{
AN ANALYSIS OF FACTORS AFFECTING UNDERSTANDING AND APPLICATIONS OF BRANDED HOUSING PROJECT MARKETING AROUND THE ISTANBUL METROPOLITAN AREA
}

DOI: 10.17261/Pressacademia.2015111602

\author{
Selcuk Polat', Murat Ferman ${ }^{2}$ \\ 1Isık University. selcuk.polat@isik.edu.tr \\ ${ }^{2}$ Isık University. mferman@isikun.edu.tr
}

\section{Keywords \\ Marketing, brand preference, brand, marketability, housing, housing sector}

JEL Classification M30, M31, M37

\begin{abstract}
Marketing is a quite crucial topic for success in the current competitive environment. Efficient and effective marketing practices will allow the companies to grow and to be more successful. Companies can gain competitive advantage by developing various marketing strategies. The objective of this study is to research the factors affecting the understanding and applications of 'branded housing project marketing' around the Istanbul metropolitan area. Branding and market positioning depend on fulfillment of certain conditions and key criteria. The criteria such as the structure of companies, product quality, professional services, and marketing and communication perspectives all constitute a quite important process in the enhancement of the perceived value of the company. Companies should be aware that it is highly vital to create brand in order to benefit from the advantages of the brand such as creating differentiation, positive high-quality corporate and brand image and customer loyalty and resolution. Today, the number of construction companies carrying out branded housing projects is quite high. It has been observed that the activities regarding branding are quite prevalent in construction industry. In line with this, every housing project should have its own identity and brand image. Especially in business fields with higher economic value such as residential real estate sector, marketing and sales activities display unique characteristics.
\end{abstract}

\section{INTRODUCTION}

This study presents a survey over the construction companies which are actively engaged in the branded residential housing projects in Istanbul metropolitan area.The critical factors leading to marketing success for construction companies are investigated through interviews with the owners and/or top-level managers. Branding and market positioning depend on fulfillment of certain conditions and key criterion. It is known that the following criterion- structure of companies, quality of the product, professional services, marketing and communications perspectives- both constitute important process and leverage to increase the perceived value of a product or overall differentiation providing costumer encouragement and maintaining overall image of high quality. 
The technological advances in recent years have led to the different changes, not only in customer demand, but also for the consequent costs of market leadership, differentiation and focus. This trend emphasizes importance of the institutionalization of branding and marketing. (Kotler, 2003). Nowadays, construction companies which build branded housing projects have already established themselves as prime actors of one of the leading and most dynamic sectors of the Turkish economy. It is an observed fact that the brand- related activities are becoming of a more strategic parameter in construction industry. In relation to this fact, each and every housing project aim to be related with a unique identity and brand image. Especially in residential real estate sector, due to the high economic values involved, marketing and sales activities are classified as crucial elements of corporate conduct.

According to regulations in Turkey, construction permit is the license allowing and authorizing a new construction work-project as a legal status. However, the significant amount of "illegal" construction lacking legal permission should be taken as a signal for urgent need of a possible revision and/or policy changes in the area. Unfortunately, nearly all of those illegal houses are of low- quality and their future presence is highly questionable and even subject to termination due to their illegal status. Clearly, these houses are vulnerable to many different legal, economic and social risks and threats. It has been observed that the governments did not hesitate to demolish these slum houses in recent years, under the context of re-structuring the metropolitan area programmes. As a result of these policies, an on-going growth can be expected in the construction of higher quality, mostly branded residential structures which may as well contribute to an overall increase in housing prices. (www.toki.gov.tr)

By planning and crafting the branding processes in a systematic fashion, construction companies can distinguish themselves in industry, gain confidence, as well as, preference of consumers by creating a high brand value image and perception (Yüksel, 2003). In Turkey, competitive environment in the construction industry is getting more challenging, as the complexity of projects in direct proportion to technological advancements is increading. This phenomenon introduces new challenges in solving problems during the stages of preliminary design, tendering and construction and after- construction services and support. When those challenges are handled in an efficient way, it is possible to contribute to stable and sustainable growth, decreasing of regional developmental differences, improvement of physical structure, and development of human resources, strengthening social networks, in a direct and indirect fashion (Göncü, 2004). As it is for all other countries of world, construction industry is considered as the locomotive sector and the major engine for providing efficiency and stability of country-wide development and strategicaly positioning in Turkey. 


\section{LITERATURE SURVEY}

It has been argued that some of the most influential factors contributing to the on-going success of a construction firm are present management systems, procedures and practices (Adrian, 1976; Lussier, 1995; Strischek, 1998). A thorough review of the literature has revealed only one significant study addressing management's perception of factors leading to the success of construction companies. In that research, the authors selected a random sample of more than 1,100 small-volume home builders and asked each one to list, in priority order, the top five things that contributed most to the success of their companies (Hutchings\&Christofferson, 2000). In other studies, marketing is found to be a critical issue to success in today's increasingly competitive business environment (Arslan, Kıvrak, et.al., 2009).

A company's growth and success can be strongly influenced by marketing practices. The aim of this study is to investigate the critical factors affecting marketing success of construction companies in the housing sector of Turkey. Within this context, a survey is carried out among forty Turkish local construction companies that are active in the housing sector. During this survey, top-level managers and/or owners of the companies are interviewed. The majority of the interviewees are happening to be the owners of these companies. In the data collection phase, a questionnaire was administered during face-to-face interviews (Arslan, Kıvrak, et.al., 2009). Six possible factors that stand to have an effect on successful marketing for construction companies in Turkey have emerged. Finally, the ranking of the critical factors have been determined by using the Simple Multi Attribute Rating Technique (SMART). Based on the results, company image and customer satisfaction are determined as the most highly vital factors for successful marketing in construction business.

There are many studies on the concept of marketing in the construction industry. Morgan (1990) investigated marketing of consulting engineering services and discovered that very few firms had their own marketing departments. Yisa et al. (1996) proposed a framework for improving the effectiveness of the marketing function within the construction companies. They concluded that a practical approach for formulating, implementing and evaluating corporate marketing programs can be represented by that framework.

Dikmen et al. (2005) examined the perception of and attitude of Turkish contractors towards marketing. They found that marketing capability was not seen as a strategic success factor by the majority of the contractors. Arslan et al. (2009) investigated the critical factors affecting marketing success of construction companies in the housing sector of Turkey. The authors identified company image and customer satisfaction as vital factors for successful marketing in construction business. Polat and Dönmez (2010) examined the marketing management functions of Turkish construction companies and revealed that Turkish contractors made use of marketing management functions, only to some extent. Çako and Çınar (2012) have established that corporate branding is as important for companies in the construction industry as with all other companies in different venues. Corporate culture of construction companies, characteristics of products or services, required quality standards, out-sourced professional services, keeping-up with technology and research are found to be important elements increasing an institution's brand value. 


\section{DATA AND METHODOLOGY}

The aim of this study is to investigate the factors affecting 'Branded Housing Project' marketing. Within this context, a survey was carried out among sixty Turkish local construction companies executives who are members of INDER (Istanbul Residential Construction Companies Association), operating in the Istanbul metropolitan area.

The survey consists of 134 questions and fifty valid collected data forms. During the datacollection period, face-to-face interviews were carried out with top-level managers and/or owners of the construction companies in the research sample.

In this study, "Descriptive survey model" is utilized. Descriptive survey model studies report summary data, such as, measures of central tendency including; mean, median, mode, deviance from the mean, variation, percentage, and correlation between variables. Survey research commonly includes that type of measurement, but often goes beyond the descriptive statistics in order to draw inferences. See, for example, Signer's (1991) survey of computer-assisted instruction and at-risk students, or Nolan, McKinnon, and Soler's (1992) research on achieving equitable access to school computers. Thick, rich descriptions of phenomena can also emerge from qualitative studies, case studies, observational studies, interviews, and portfolio assessments. Robinson's (1994) case study of a televised news program in classrooms and Lee's (1994) case study about identifying values concerning school restructuring are excellent examples of case studies.

\subsection{Research Method}

Before any survey-related work done, a research model is established in figure 1 .The purpose of the model is to determine factors affecting companies' marketing, promotion and sales practices as well as understanding the application of marketing methods in practice.

Figure1: Research Model; Factors Affecting the Understanding and Applications of 'Branded Housing Project' Marketing

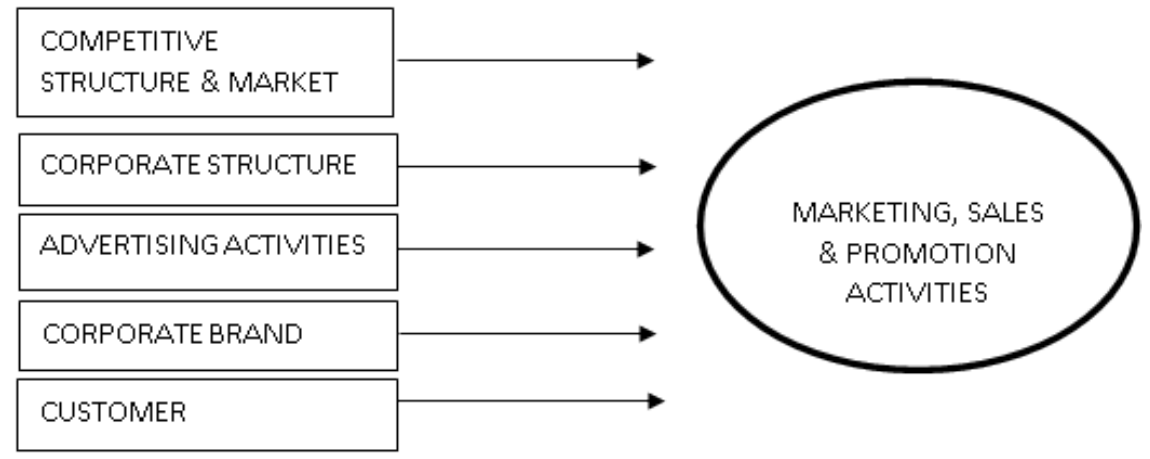

Once again, the basic aim of this research is to determine the factors affecting the understanding and applications of marketing 'branded housing project.' In line with this research objective, answers to the following questions are sought: 
A) Company Information

B) Marketing and Sales Activities

C) Marketing and Promotion Activities

D) Competitive Structure and Market Conditions

F) Brand Orientation Perspective

G) Advertising Activities

H) Brand Value of Organization

I) Customer Satisfaction

\section{Basic Research Question is:}

Which factors do affect the understanding and applications of 'branded housing project' marketing in the Istanbul metropolitan area?

\subsection{Research Population}

Sixty construction companies, which are members of INDER (Istanbul Residential Construction Companies Association) and involve only in branded housing projects constitute the research population. Feedback was received from 50 of these companies' executives/owners.

\subsection{Data Collection Methods}

For the field study, a questionnaire is designed to gather information about the Istanbul Builder's Association Companies activities for marketing, advertising, promotion and branding works.

Furthermore, the questionnaire followed the same structure as the interview guideline, where the questions were connected to the concepts of Marketing, customer relationship, promotion methods, corporate structure, brand value of corporation, competitive structure and market conditions.

5- Likert scale survey method was used in data acquisition. Attention was paid for addressing comprehensible questions to the participants when the survey form was prepared. Likert scale used in the study of people with their opinions about the proposition, from very positive to very negative were asked to specify the options listed. Accordingly, (5) strongly agree, (4) agree, (3) undecided, (2) disagree, (1) strongly disagree was used as a scale. 5:00 to 1:00 Scale results are scattered over a width of $=4.00$ percentage points.

\subsection{Data Analysis Methods}

Once the data from the questionnaire had been collected, the next step was to analyze and present the data using different methods. According to Hair et al. (2011); good research is the result of a careful, thoughtful and knowledgeable approach, using qualitative or quantitative research analysis methods. Yin (2009) states that the data 
analysis is implemented in the thesis since it helps categorizing, measure and presents the collected data in a clear and structured way.

The operationalization of the questionnaire helped the authors to code the questionnaire statements so that each concept of Brand value of organization, marketing activities, customer satisfaction, market conditions, advertising activities and competitive structure could be analyzed. Thereafter, used the statistical computer program IBM SPSS 22 version utilized to edit and transform the data and calculate percentages for each questionnaire statement. In the second step of the quantitative data analysis, available data presented using descriptive statistics, more specifically bar and pie charts. These types of charts are chosen since they provided the reader with the best visualization and understanding of the data. Data is analyzed by using the SPSS (Statistical Package for Social Sciences) for IBM 22.0 version. The descriptive statistical methods, (number, percentage, mean, standard deviation, frequency) are utilized for the variables. Extension of data files is "sav" and extension of analysis outputs is "spv." In comparing quantitative data, when there is the case of more than two groups; Kruskal Wallis H-Test is utilized for comparison of parameters' intergroup. A relation between the dependent and independent variables of the research is tested by Spearman Correlation and the related effect is tested by Regression Analysis (Stepwise Regression).The findings obtained in 95\% confidence interval are evaluated at the $5 \%$ significance level.

\section{EMPIRICAL FINDINGS}

Regarding personnel numbers; companies with more than 100 people are a total of 23 companies (\%46), between 1-24 people, a total of 16 companies (\%32) and with 25-99 people consist of 11 companies (\%22). In order to determine the statistically significant differences between marketing concept and applications and technical and administrative employees in the company the Kruskal-Wallis H-Test is utilized. According to the results, the average difference between groups was not significant $(p>0.05)$.

Regarding the ownership of quality certificates; 34 companies (\%68) have ISO9001 (QualityManagementSystem), 8 of them (\%16) have OHSAS18001 (Workplace Safety Management System) and the remaining 8 (\%16) do have another. In order to determine the statistically significant differences between marketing concept and applications, and quality certificate of the company the Kruskal-Wallis $\mathrm{H}$-Test is utilized. According to the results, the average difference between groups was not significant ( $p>0.05)$. Tools for advertising help companies attract most attention to business and reach the largest number of potentially new and returning customers. The most used advertisement is printed media an observed practice for 43 (\%86) companies. It is followed by the tools respectively internet (\%82), billboard (\%72), brochure/flyers (\%68) mass media (\%64) and bus and taxi (\%64).

Customer satisfaction was perceived to be the most important factor resulting in marketing success when considering the weights of importance of the factors. The are expected to have more developed marketing perception. Companies must include more element their projects which emphasize on satisfying customer needs. Companies include the project elements with an emphasize on customer satisfaction can be listed 
respectively as smart home technology (82\%), social facilities (\%70), parks and green space field (\%68), fitness center (\%64), car park (62\%), outdoor/indoor pool (60\%), health unit (\%56) and shopping center facilities (42\%).

When findings regarding the major reasons of customer choice are considered, it can be seen that the most important factors are contractor firm's reliability by $86 \%$ and site security by $86 \%$. These two factors are followed by price and payment system by $54 \%$, size of house by $54 \%$, open and close parking garage by $60 \%$, high quality materials in construction $66 \%$, quality of the house $60 \%$ and the location of the residential complex $58 \%$. In this research, the relations between factors which affect branded house project marketing sense and applications have been analyzed by using spearman correlation analysis. As a result, it is determined that there exists a positive meaningful relationship between the factors which affect branded house project marketing and applications of construction companies out of competitive structure and marketing conditions. It is clear that competitive structure of the industry and market conditions are external factors in construction companies, where marketing sense and applications and other factors are highly intertwined with each other.

The factors which affect branded house project marketing sense and application are; "Competitive Structure and Marketing Conditions", "Corporate Structure", "Advertising Activities", "Brand Equity of Corporation", "Customer Satisfaction" and "Marketing, Sale and Promotional Activities", they are analyzed in six dimensions and assessed out of five. "Marketing, sales and promotion activities" levels (4.125 \pm 0.297$)$; "competitive structure and market conditions" levels (3.890 \pm 0.428$)$; "corporate structure" level is very high (4.218 \pm 0.212$)$; "advertising activities" level is very high (4.260 \pm 0.236$)$; "corporate brand value" level is very high (4.291 \pm 0.171$)$, and "customer satisfaction" level is very high (4.300 \pm 0.199$)$. Figure 2 , demonstrates average factors affecting marketing concept and application in table 1.

Table 1: Branded Housing Project Marketing Factors Affecting the Average

\begin{tabular}{llllll}
\hline Factors Affecting the Average & N & Ort & Ss & Min. & Max. \\
\hline Marketing, Sales and Promotion Activities & 50 & 4,125 & 0,297 & 3,030 & 4,530 \\
Competitive Structure and Market Conditions & 50 & 3,890 & 0,428 & 2,880 & 4,500 \\
Corporate Structure & 50 & 4,218 & 0,212 & 3,800 & 4,600 \\
Advertising Activities & 50 & 4,260 & 0,236 & 3,670 & 4,670 \\
Corporate Brand Value & 50 & 4,291 & 0,171 & 3,920 & 4,620 \\
Customer Satisfaction & 50 & 4,300 & 0,199 & 3,780 & 4,670 \\
\hline
\end{tabular}

According to it, the importance of the factors which effect branded house project marketing sense and application are respectively; "Customer Satisfaction" (Ave: 4,300), "Corporate Brand Value" (Ave: 4,291), "Advertising Activities" (Ave: 4,260), "Corporate 
Structure" (4,218), "Marketing, Sale and Promotional Activities" (Ave: 4,125) and "Competitive Structure and Marketing Conditions" (Ave: 3,89 ) in figure 2.

Figure 2: Factors Affecting the Branded Residential Project Marketing Concept and Application Average

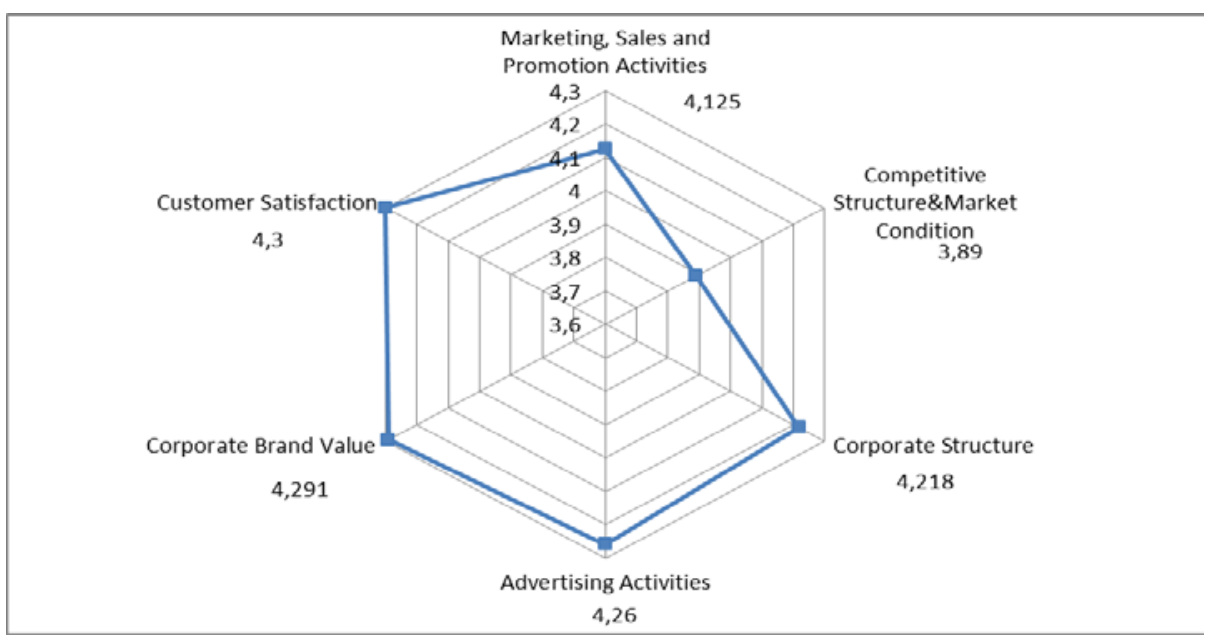

There is not a statistically significant correlation between competitive structure \& market conditions and marketing, sales \& promotion activities. Statistically significant correlation is not found between the corporate structure and marketing, sales and promotion activities $(r=0.658, p=0.000<0.05)$. Accordingly, corporate structure increases and also marketing, sales and promotion activities are increasing. There is not a statistically significant relationship between corporate structure and the competitive structure \& market conditions.

Statistically significant correlation was found between the advertising activities and marketing, sales and promotion of activities( $r=0.376, p=0.007<0.05)$. Accordingly, advertising activities increases and also, marketing, sales and promotion activities is increasing. There is not a statistically significant relationship between advertising activities and competitive structure \& market conditions. Advertising activities of corporate structure statistically significant correlation was found $(r=0.457, p=0.001<0.05$ ). Accordingly when advertising activities increase also corporate structure is increasing.

Statistically significant correlation was found between the corporate brand value activities and marketing, sales $\&$ promotion activities $(r=0.503, p=0.000<0.05)$. Accordingly, the corporate brand value increases, marketing, sales and promotion activities are increasing. There is not a statistically significant relationship between corporate brand value and competitive structure \& market conditions. Corporate brand value activities and corporate structure statistically significant correlation was found $(r=0.695, p=0.000<0.05)$. According to this corporate structure are increasing brand value increases .Statistically 
significant correlation was found with the corporate brand value activities and advertising activities $(r=0.424, p=0.002<0.05)$. Accordingly when the corporate brand value increases advertising activities is increasing.

Statistically significant correlation was found between the customer satisfaction and the marketing, sales and promotion activities ( $r=0.449, p=0.001<0.05)$. Accordingly, customer satisfaction increases and also marketing, sales and promotion activities is increasing. There is not a statistically significant relationship between customer satisfaction and competitive structure \& market conditions. Statistically significant correlation was found with the customer satisfaction and the corporate structure $(r=$ $0.448, p=0.001<0.05)$. Accordingly, the corporate structure increases and also customer satisfaction is increasing. Statistically significant correlation was found between the advertising activities and the customer satisfaction $(r=0.445, p=0.001<0.05$ ). Accordingly, increases customer satisfaction and also advertising activities is increasing. Statistically significant correlation was found between customer satisfaction and corporate brand value $(r=0.483, p=0.000<0.05)$. Accordingly when customer satisfaction increases and also corporate brand value is increasing.Depending on the above findings and analysis, it is possible to pull together the collected findings in table 2.

Table 2: Spearman Correlation Analysis of Marketing Concept and Application

\begin{tabular}{|c|c|c|c|c|c|c|c|}
\hline & & $\begin{array}{l}\text { Marketing, } \\
\text { Sales and } \\
\text { Promotion } \\
\text { Activities }\end{array}$ & $\begin{array}{l}\text { Competitive } \\
\text { Structure } \\
\text { and Market } \\
\text { Conditions }\end{array}$ & $\begin{array}{l}\text { Corporate } \\
\text { Structure }\end{array}$ & $\begin{array}{l}\text { Advertising } \\
\text { Activities }\end{array}$ & $\begin{array}{l}\text { Corporate } \\
\text { Brand } \\
\text { Value }\end{array}$ & $\begin{array}{l}\text { Customer } \\
\text { Satisfaction }\end{array}$ \\
\hline $\begin{array}{l}\text { Marketing, } \\
\text { Sales and } \\
\text { Promotion } \\
\text { Activities }\end{array}$ & $\begin{array}{l}r \\
p\end{array}$ & $\begin{array}{l}1,000 \\
0,000\end{array}$ & & & & & \\
\hline $\begin{array}{l}\text { Competitive } \\
\text { Structure } \\
\text { and Market } \\
\text { Conditions }\end{array}$ & $\begin{array}{l}r \\
p\end{array}$ & $\begin{array}{l}0,270 \\
0,058\end{array}$ & $\begin{array}{l}1,000 \\
0,000\end{array}$ & & & & \\
\hline $\begin{array}{l}\text { Corporate } \\
\text { Structure }\end{array}$ & $\begin{array}{l}r \\
p\end{array}$ & $\begin{array}{l}0,658^{* *} \\
0,000\end{array}$ & $\begin{array}{l}0,257 \\
0,071\end{array}$ & $\begin{array}{l}1,000 \\
0,000\end{array}$ & & & \\
\hline $\begin{array}{l}\text { Advertising } \\
\text { Activities }\end{array}$ & $\begin{array}{l}\mathrm{r} \\
\mathrm{p}\end{array}$ & $\begin{array}{l}0,376^{* *} \\
0,007\end{array}$ & $\begin{array}{l}0,156 \\
0,278\end{array}$ & $\begin{array}{l}0,457^{* *} \\
0,001\end{array}$ & $\begin{array}{l}1,000 \\
0,000\end{array}$ & & \\
\hline $\begin{array}{l}\text { Corporate } \\
\text { Brand Value }\end{array}$ & $r$ & $0,503 * *$ & 0,231 & $0,695^{* *}$ & $0,424 * *$ & 1,000 & \\
\hline & $p$ & 0,000 & 0,106 & 0,000 & 0,002 & 0,000 & \\
\hline Customer & $r$ & $0,449 * *$ & 0,182 & $0,448 * *$ & $0,445^{* *}$ & $0,483^{* *}$ & 1,000 \\
\hline Satisfaction & $\mathrm{p}$ & 0,001 & 0,205 & 0,001 & 0,001 & 0,000 & 0,000 \\
\hline
\end{tabular}

Determine the statistical relationship among competitive structure and market conditions, corporate structure, advertising activities, corporate brand value, customer satisfaction, 
and marketing, sales\& promotion activities is used the regression analysis and found to be statistically significant $(F=6.709, p=0.000<0.05)$.

Statistically relations and variables between marketing, sales \&promotion activities and competitive structure \&market conditions, corporate structure, advertising activities, corporate brand value and customer satisfaction is proved stronger and explanatory power. $(\mathrm{R} 2=0.368)$. Competitive structure and market conditions affect the marketing sales and promotion activities on level $(p=0.130>0.05)$.Corporate structure and market condition increase marketing, sales and promotion activities on level ( $\beta=0.509$ ).

Advertising activities affect the marketing, sales and promotion activities level $(p=0.495>$ 0.05 ). Corporate brand value affect marketing, sales and promotion activities level ( $p=$ $0.659>0.05)$. Customer satisfaction affect marketing, sales and promotion activities level $(p=0.129>0.05)$ in table 3 .

Table 3: Statistical Relationship between "Branded Residential Project" Marketing Concept \& Applications and Marketing, Sales \& Promotion Activities

\begin{tabular}{|c|c|c|c|c|c|c|c|}
\hline $\begin{array}{l}\text { Dependent } \\
\text { Variable }\end{array}$ & Independent Variable & ß & $\mathbf{t}$ & $p$ & $\mathbf{F}$ & $\begin{array}{l}\text { Model } \\
\text { (p) }\end{array}$ & $\mathbf{R}^{2}$ \\
\hline \multirow{6}{*}{$\begin{array}{l}\text { Marketing, } \\
\text { Sales and } \\
\text { Promotion } \\
\text { Activities }\end{array}$} & constant & $-0,870$ & $-0,912$ & 0,367 & \multirow[t]{6}{*}{6,709} & \multirow[t]{6}{*}{0,000} & \multirow[t]{6}{*}{0,368} \\
\hline & $\begin{array}{l}\text { Competitive Structure } \\
\text { and Market Conditions }\end{array}$ & 0,125 & 1,543 & 0,130 & & & \\
\hline & Corporate Structure & 0,509 & 2,247 & 0,030 & & & \\
\hline & Advertising Activities & 0,116 & 0,688 & 0,495 & & & \\
\hline & Corporate Brand Value & 0,124 & 0,444 & 0,659 & & & \\
\hline & Customer Satisfaction & 0,310 & 1,546 & 0,129 & & & \\
\hline
\end{tabular}

In order to Statistically determine the relations between corporate structure, customer satisfaction and the marketing, sales and promotion activities, stepwise regression analysis is conducted and found to be statistically significant $(F=15.159, p=0.000<0.05)$ in table 4.

Table 4: Stepwise Regression Analysis of the "Branded Residential Project" Marketing Concept \& Applications Factors Affecting the Marketing, Sales Promotions Activities

\begin{tabular}{llllllll}
\hline \multicolumn{1}{c}{$\begin{array}{c}\text { Dependent } \\
\text { Variable }\end{array}$} & $\begin{array}{l}\text { Independent } \\
\text { Variable }\end{array}$ & $\mathbf{B}$ & $\mathbf{t}$ & $\mathbf{p}$ & $\mathbf{F}$ & $\begin{array}{l}\text { Model } \\
\mathbf{( p )}\end{array}$ & $\mathbf{R}^{\mathbf{2}}$ \\
\hline Marketing, Sales & constant & $-0,363$ & $-0,432$ & 0,667 & 15,159 & $\mathbf{0 , 0 0 0}$ & 0,366 \\
and Promotion & Corporate & 0,661 & 3,788 & $\mathbf{0 , 0 0 0}$ & & & \\
Activities & $\begin{array}{l}\text { Structure } \\
\text { Customer }\end{array}$ & 0,396 & 2,130 & $\mathbf{0 , 0 3 8}$ & & & \\
& Satisfaction & & & & & & \\
\hline
\end{tabular}

Marketing, sales and promotion activities as a determinant of the level of corporate structure, customer satisfaction with the relationship between variables (explanatory power) was found to be strong $(R 2=0.366)$. 
Corporate structure increase marketing, sales and promotion activities level $(\beta=$ 0.661).While customer satisfaction increase marketing, sales and promotion activities level $(ß=0.396)$ in figure 3 .

\section{Figure 3: Stepwise Regression Analysis of the "Branded Residential Project" Marketing} Concept \& Applications Factors Affecting the Marketing, Sales Promotions Activities

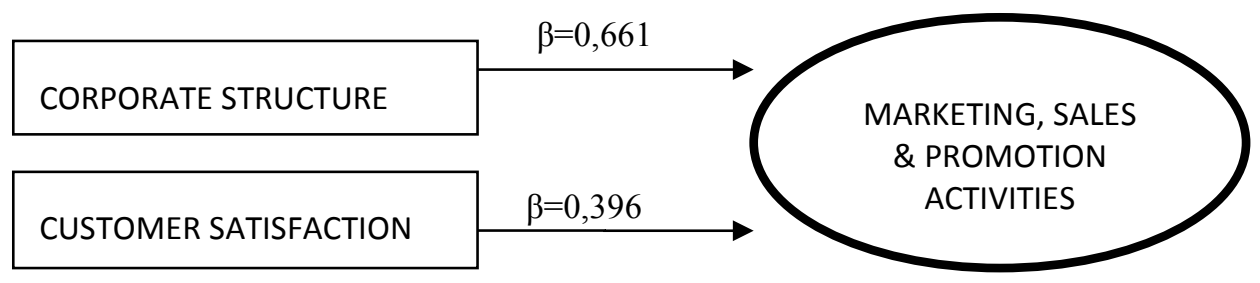

It is determined that corporate structure and customer satisfaction effect directly marketing, sales and promotion activities.

\section{CONCLUSION}

This study presents factors of marketing practice and applications of 'branded housing projects' around the Istanbul metropolitan area. The critical factors of marketing practice and applications have been investigated through interviews among top-level managers and owners of the companies.

Customer satisfaction and corporate structure are perceived to be the most important factors resulting in marketing success when considering the importance of the factors. Competitive structure and market conditions are both determined as relatively less important factors leading to marketing performance.

In the research, stepwise regression analysis has been utilized in order to determine the factors of, sales and promotional activities and it is determined that corporate structure and customer satisfaction affect directly marketing, sales and promotional activates.

The most important issue for companies appears to be customer's satisfaction. In order to ensure customer confidence, for residential warranty or buy back guarantee must be provided at the end of a certain period. Customer satisfaction in customer understanding of quality services accordingly standard of identification, problem solving, and for the establishment of a team regular check must be provided Customer wants, needs and requests should be understood very well by the marketing departments and should be organized by them. From this point of view, social-economic structure of the customers is very important for residential housing sales.

Construction companies are now offering products for any income level with flexible payment plans. By this way, reaching a balance between supply and demand is being achieved which happened to be a long term challenge for the industry. Different customer 
groups for different types of housing should be provided. Using latest building technologies should be use state-of-the-art-of technologies such as intelligent building should be utilized.

Companies must consider the fact that carrying out only advertising and media communication activities is not enough, and therefore they should assume more active roles buy participation to exhibitions and conferences, social activities, sponsorship activities, donation and scholarship activities.

In this ever-changing business environment it is difficult for companies to develop their strategies fast enough. Companies want an organization flexible enough to adjust quickly to changing market conditions, lean enough to beat competitor's price, innovative enough to keep its products and services technologically fresh, and dedicated enough to deliver maximum quality and customer service.

The comprehension of the new ascending technologies, the foresight of the changes in the business environment and, when needed, a capability to differentiate are necessary in order to attain a continuous competitive advantage in the business. Technology road mapping is one possible tool for long-term strategic planning at both corporate and industry level.

There are many construction associations in Istanbul. If they assemble under in a single association they will enjoy a stronger unison and their presence would be more powerful.

The research model is tested with the results generated from 50 companies of the research population. More numerous and different characteristics of such models can be tested by utilizing a larger research population, and could generate from different areas paving the way for an increased positive effect on overall validity of further studies.

\section{REFERENCES}

Arslan, G., Kıvrak, S., and Tankişi, M. (2009) Factors Affecting Marketing Success for Construction Companies in the Housing Sector. Fifth International Conference on Construction in the 21st Century.

Çako, S. and Çınar, C. (2012) YTÜ Master Thesis, A Study on the Criteria for Branding Contractor Construction Sector Companies in Turkey.Yıldız Technical University, Faculty of Architecture, İstanbul, Turkey.

Dikmen, and M. T. Birgonul (2005) Strategic Perspective of Turkish Construction Companies, Journal of Management in Engineering,19(1), 33-40.

Göncü, Ü. (2004) Konut Pazarlama Stratejileri. Yüksek Lisans Tezi, İ.T.Ü. Fen Bilimleri Enstitüsü, İstanbul.

Hutchings, M. and Christofferson, J. (2001) Factors Leading to Construction Company Success: Perceptions of Small-Volume Residential Contractors. ASC Proceedings of the 37th Annual Conference.

Kivrak, S. and Arslan, G. (2008) Critical Factors to Company Success in the Construction Industry. World Academy of Science, Engineering and Technology.

Kotler, P. (2003) Marketing Management. New Jersey, Prentice Hall. 
Polat,G. and Donmez, U. (2010) Marketing Management Functions Of Construction Companies:Evidence FromTurkish Contractors. Journal Of Civil Engineering And Management 16(2): 267-277.

Strischek, D. (1998) Red Warning Flags of Contractor Failure. Journal of Lending \& Credit Risk Management 80, (11), 40-47.

Tuncel, K. (2011) Gayrimenkulde Pazarlama Süreci, Proje Yönetim A.Ş. Turgut Özal Bulvarı Gardenya Plaza-1 Kat 6 Ethos Salonu Ataşehir/istanbul.

Yisa, S.and Ambrose, B. (1996) A Review of Changes in the UK Construction Industry: Their Implications for the Marketing of Construction Services. J. Mark., 30 (3): 47-64.

Yüksel, Y. (2003) Konut Mekanı Kavramının Tipolojik Temelleri.íü Mimarlik Fakültesi Matbaası, İstanbul. 